\title{
INTENSI PELANGGARAN BATAS KECEPATAN MAKSIMAL DI ZONA SELAMAT SEKOLAH
}

\author{
* Sri Handayani ${ }^{1}$, Sarinah Sihombing ${ }^{2}$, Sumillah Irwan $^{3}$, Tri Mulyani Setyowati ${ }^{4}$ \\ 1,2,3,4 Institut Transportasi dan Logistik Trisakti, Jakarta, Indonesia
}

*Email Korespondensi:

srihandayaniaddress@gmail.com

\section{ARTIKEL INFORMASI}

Diterima:

25 Juni 2021

Direvisi:

12 Juli 2021

Dipublikasi:

22 Juli 2021

\begin{abstract}
ABSTRAK
Penelitian ini menganalisis tentang aspek penting dalam intensi pelanggaran batas kecepatan maksimal di Zona Selamat Sekolah (ZoSS) di DKI Jakarta khususnya lima wilayah yang berbeda yaitu Jakarta Pusat, Jakarta Timur, Jakarta Selatan, Jakarta Barat dan Jakarta Utara. Metode yang digunakan adalah metode kuantitatif, dimana data yang diperoleh disajikan dalam bentuk angka (numerik) dan dianalisis lebih lanjut menjadi delapan variabel penelitian, yaitu Intensi Pelanggaran Batas Kecepatan Maksimal sebagai variabel terikat (dependent variable), Sikap, Norma Subjektif, Pengendalian Terukur, Gender, Usia, Pendidikan, dan kepemilikan SIM sebagai variabel bebas (independent variable). Penelitian ini menggunakan data primer yang dilakukan dengan survei online di bulan Juni dan Juli 2020. Survei didistribusikan melalui media sosial di berbagai kelompok pendidikan dan pusat komunitas di Jakarta. Dari data yang didapatkan dan analisis yang telah dilakukan, maka penelitian ini membuktikan bahwa berdasarkan uji t (t-test) hanya variabel Norma Subjektif (Norma) yang berpengaruh signifikan terhadap Intensi Pelanggaran Batas Kecepatan Maksimal di ZoSS, hal ini memberikan penjelasan bahwa pengaruh lingkungan berupa nilai-nilai di masyarakat signifikan mencegah terbentuknya niat ngebut yang dapat membahayakan dan dapat merugikan diri sendiri dan orang lain. Dengan adanya pengaruh dan sanksi sosial jika melakukan perilaku itu, maka adanya Intensi Pelanggaran Batas Kecepatan Maksimal di ZoSS dapat diminimalkan..
\end{abstract}

Kata Kunci: Intensi, Zona Selamat Sekolah (ZoSS), Ngebut, Keselamatan Jalan, Norma Subjektif, Pengendalian Terukur

\section{PENDAHULUAN}

Wilayah Provinsi DKI Jakarta memiliki luas sebesar $661.5 \mathrm{Km}^{2}$, dengan kepadatan penduduk sebanyak 15.367 orang $/ \mathrm{km}^{2}$ dan jumlah sekolah yang berlokasi di DKI Jakarta dari tingkat sekolah dasar sampai dengan tingkat sekolah menengah atas adalah sebanyak 4.573 sekolah (tanpa kabupaten kepulauan seribu) (Data Sekolah Provinsi DKI Jakarta, n.d.). 


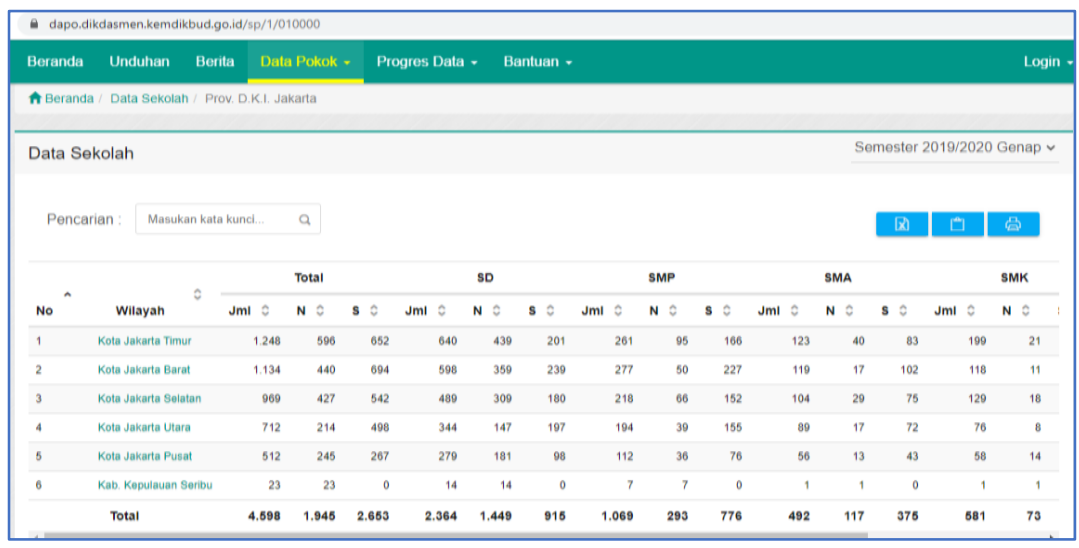

Gambar 1. Data Sekolah Provinsi DKI Jakarta

Sumber: Data Sekolah Provinsi DKI Jakarta.

Pelajar merupakan pengguna jalan yang tidak berpengalaman dan cenderung kurang hati-hati, sehingga pelajar seringkali menjadi korban kecelakaan lalu lintas (Kamal, Wulandari, \& Gunawan, 2019). Sebagai pengguna jalan, baik sebagai pejalan kaki, pengendara sepeda, pengemudi kendaran bermotor roda dua, tiga, empat, atau lebih dari empat, jalan dapat menghubungkan orang dengan orang lain, tempat yang satu dengan tempat lain atau bahkan kebudayaan yang satu dengan kebudayaan lain. Pada tataran yang lebih praktis, jalan merupakan sarana untuk bepergian ke tempat kerja dan mengangkut barang (Red Cross, 2007), sehingga ketersediaan jalan, yang menciptakan permintan derivatif dalam industri transportasi dan logistik.

Jumlah kendaraan bermotor pada tahun 2017 adalah 138.556 .669 unit, dimana pertumbuhan dalam dua tahun terakhir mencapai angka 6-7 persen per tahun. Kontributor terbesar untuk pertumbuhan tersebut adalah sepeda motor (Indonesian Central Agency of Statistics, 2019a). Dari paparan diatas, dapat dikatakan bahwa isu keselamatan jalan tidak hanya dilihat dari tidak adanya kecelakaan yang terjadi, melainkan lebih luas karena isu ini juga penting untuk menciptakan lingkungan yang aman, nyaman dan menjamin keselamatan bagi pengguna jalan (Handayani, Mulyani, \& Iqbal, 2019).

Menurut WHO (World Health Organization, 2014) kecelakaan lalu lintas adalah penyebab utama kematian di dunia bagi orang berusia 15-29 tahun. Sementara, Jakarta Open Data menunjukkan bahwa di tahun 2013 dari 3.710 kejadian kecelakaan lalu lintas mengakibatkan korban kematian sebanyak 401 orang dan mayoritas korban meninggal berumur antara 10-30 tahun (Indonesian Central Agency of Statistics, 2019). Pada tahun 2018, jumlah penduduk Jakarta yang berusia antara 15 sampai dengan 39 tahun mendekati angka 49 persen dari total penduduk Jakarta (bps file jumlah penduduk jakarta menurut kelompok umur, n.d.), sehingga kelompok umur ini lebih dominan dianggap sebagai pengguna jalan.

Adanya keterbatasan dan belum meratanya sarana dan prasarana transportasi darat di kota Jakarta mengakibatkan kemacetan di titik-titik wilayah tertentu yang terkonsentrasi di Pusat Kota, peningkatan biaya transportasi, kerugian dari sisi waktu serta penurunan terhadap keselamatan transportasi (Perwitasari, Setyowati \& Handayani, 2020). Berdasarkan data BPS yang tersedia di tahun 2013, diketahui bahwa setiap hari terjadi 10 kejadian kecelakaan lalu lintas di DKI Jakarta. Tabel dibawah ini menunjukkan 28 titik rawan kecelakaan di wilayah DKI Jakarta (Republika, n.d.):

Tabel 1. 28 Titik Rawan Kecelakaan di DKI Jakarta

\begin{tabular}{ll}
\hline Jakarta Pusat & - Jalan Angkasa dari arah barat ke timur \\
& - Jalan Gerbang Pemuda, Senayan \\
\hline Jakarta Utara & - Jalan Lodan Raya \\
& - Jalan R.E Martadinata Jembatan PLTU \\
& - Jalan Yos Sudarso \\
& - Jalan Raya Cakung-Cilincing (Cacing) \\
\hline Jakarta Barat & - Jalan Raya Daan Mogot \\
& - Jalan Raya Tubagus Angke \\
\hline Jakarta Selatan & - Jalan Sultan Iskandar Muda arah selatan \\
\hline
\end{tabular}




\begin{tabular}{ll}
\hline & - Jalan Raya Pasar Minggu arah selatan \\
- & Jalan Raya TB Simatupang arah barat \\
- & Jalan Prof. Dr. Saharjo \\
- & Jalan KH. Abdullah Syafei \\
\hline & - Jalan Bogor arah ke Selatan dan arah utara, Kecamatan \\
& Ciracas \\
- & Jalan I Gusti Ngurah Rai arah ke barat dan arah timur, \\
& Kecamatan Duren Sawit \\
- & Jalan KRT Dr Rajiman Widyodiningrat arah ke utara dan \\
& arah selatan, Kecamatan Cakung \\
\hline
\end{tabular}

Sumber: Republika, 2019

Pemerintah Indonesia menerapkan Zona Selamat Sekolah (ZoSS) Dalam rangka meningkatkan keselamatan jalan sejak tahun 2006, yaitu lokasi di ruas jalan tertentu (Tanggal et al., n.d.) yang merupakan zona kecepatan berbasis waktu untuk mengatur kecepatan kendaraan di lingkungan sekolah. Batas kecepatan yang sudah ditetapkan untuk ZoSS adalah sekitar 20 sampai dengan 25 kilometer/jam. Pemaparan diatas memberikan gambaran betapa padatnya situasi lalulintas di sekitar ZoSS pada pagi hari dan pada saat pulang sekolah, sehingga penerapan Zona Selamat Sekolah sangat penting.

Salah satu faktor dari lima risiko utama penyebab kecelakaan lalu lintas dan penyebab kematian adalah perilaku memacu kendaraan melebihi batas kecepatan yang ditentukan (World Health Organization, 2014). Perilaku ngebut ini memiliki keterkaitan langsung terhadap penyebab dan parahnya kecelakaan yang terjadi. Ngebut terdiri dari dua perilaku yang berbeda yaitu melebihi batas kecepatan dan ngebut yang berlebihan. Oleh karena itu, intensi dapat dijadikan sebagai pendekatan dasar yang masuk akal untuk memahami bagaimana pelanggaran batas kecepatan maksimal di Zona Selamat Sekolah. Identifikasi atas intensi pelanggaran batas kecepatan maksimal ini dapat berpotensi menyelamatkan jiwa dan mengurangi biaya keselamatan berlalulintas melalui peningkatan perilaku pengemudi

Penelitian ini menganalisis tentang aspek penting dalam intensi pelanggaran batas kecepatan maksimal, sehingga dengan melakukan penelitian ini, diharapkan dapat memberikan gambaran secara menyeluruh mengenai intensi pelanggaran batas kecepatan maksimal di Zona Selamat Sekolah (ZoSS) di DKI Jakarta khususnya lima wilayah yang berbeda yaitu Jakarta Pusat, Jakarta Timur, Jakarta Selatan, Jakarta Barat dan Jakarta Utara.

\section{KAJIAN PUSTAKA}

\section{Intensi (Niat/Intention) Pelanggaran Batas Kecepatan Maksimal}

Intensi mencerminkan representasi kognitif pada kesiapan individu untuk melakukan tindakan tertentu (Ajzen, 1991). Intensi (niat) cenderung menjadi prediktor terbaik dari suatu tindakan tunggal seperti niat untuk membaca suatu buku atau niat untuk menghadiri kuliah seorang dosen (Sheeran, 2017), bahkan niat untuk melakukan pelanggaran batas kecepatan maksimal dalam berkendara.

Secara garis besar, individu menyadari tindakan yang diperlukan untuk mencapai tujuan tertentu (From Intentions to Actions: A Theory of Planned Behavior, 1985). Misalnya, perilaku yang relatif rutin dalam mengemudi mobil. Mengemudi kendaraan atau berkendara dengan kecepatan diatas batas kecepatan yang diperbolehkan dikenal dengan istilah Ngebut. Perilaku mengemudi tanpa memperhatikan aturan lalu lintas, misalnya dengan kecepatan yang melebihi batas kecepatan yang telah ditetapkan, berpotensi mengakibatkan kecelakaan dan dapat menimbulkan dampak merugikan lainnya. Berdasarkan penelitian sebelumnya (Jones, Ferguson, \& Robinson, 2012), intensi untuk ngebut didasarkan pada sikap individu, perceived behavioral control and sense of arousal.

\section{Sikap (Attitude) \\ Sikap adalah tingkah laku atau gerakan-gerakan yang tampak dan ditampilkan dalam interaksinya dengan lingkungan sosial. Interaksi tersebut dapat proses saling merespon, saling mempengaruhi serta saling menyesuaikan diri dengan lingkungan sosial. Berdasarkan karakternya, sikap merupakan reaksi atau respon yang masih tertutup dari seseorang terhadap suatu stimulus atau objek. Sikap secara nyata menunjukkan}


konotasi adanya keserasian reaksi dengan stimulus atau rangsangan tertentu yang diperoleh dalam kehidupan sehari-hari individu dan bersifat emosional terhadap stimulus atau ransangan dari lingkungan sekitarnya.

Sikap merupakan kesediaan atau kemauan untuk bertindak, dan bukan merupakan realisasi dari intensi tertentu. Berdasarkan hal tersebut dapat dikatakan bahwa sikap belum menjadi suatu tindakan atau kegiatan. Sikap mempunyai tiga komponen pokok yaitu kepercayaan yang merupakan ide dan konsep terhadap suatu objek, penilaian atas suatu objek, dan kcenderungan untuk bertindak (Allport, 1954). Ketiga komponen dari sikap tersebut bersama-sama membentuk sikap yang utuh.

Terdapat beberapa tingkatan sikap dilihat dari indikasinya. Indikasi yang pertama adalah menerima, dimana subjek mau dan memperhatikan stimulus yang diberikan objek. Indikasi sikap yang kedua adalah merespon, dimana subjek memberikan jawaban apabila ditanya, mengerjakan dan menyelesaikan tugas yang diberikan. Indikasi ketiga adalah menghargai, mengajak orang lain untuk mengerjakan atau mendiskusikan suatu masalah. Indikasi yang terakhir dari sikap adalah bertanggung jawab atas segala sesuatu yang telah dipilihnya dengan segala risiko (Notoatmodjo, 2003).

Sikap dalam kaitannya dengan stimulus yang relevan akan menentukan jenis tabiat tingkah laku individu atau peristiwa. Sikap adalah faktor internal dan memiliki ciri-ciri sebagai berikut: sikap merupakan hasil belajar, sikap menjadi stabil melalui pengalaman, sikap melibatkan hubungan antara individu dan individu lain dan juga antara individu dengan benda atau situasi, sikap berisi cognity atau informasi yang faktual misalnya menyenangkan atau tidak menyenangkan, sikap merupakan pendekatan atau penghindaran secara langsung (Ahmadi, 1999).

\section{Norma Subjektif (Subjective Norm)}

Norma subjektif adalah persepsi seseorang mengenai tekanan sosial untuk melakukan atau tidak melakukan perilaku (Ajzen,1988). Dalam model Theory of Reasoned Action dan Theory of Planned Behavior, norma subjektif adalah fungsi dari normative beliefs, yang mewakili persepsi mengenai penilaian masyarakat yang sigifikan mengenai apakah perilaku tersebut harus dilakukan.

Norma subjektif mengacu pada keterlibatan perasaan akan tekanan sosial dalam sebuah perilaku (Hakim \& Nuqul, 2011). Norma-norma moral merupakan persepsi individu terhadap kebenaran moral atau ketidaktepatan melakukan perilaku (Ajzen, 1991) dan memperhatikan perasaan pribadi terhadap tanggung-jawab untuk melakukan atau menolak untuk melakukan perilaku tertentu. Norma-norma moral diharapkan memiliki pengaruh penting pada kinerja perilaku-perilaku dengan dimensi moral dan etika. Norma-norma moral merupakan nilai-nilai yang dianut atau kesepakatan anggota-anggota kelompok, sedangkan individu dalam berperilaku dipengaruhi oleh norma kelompok tersebut, termasuk dalam perilaku berlalu-lintas, khususnya perilaku mengemudi. Perilaku mengemudi merupakan perilaku mora karena berpotensi menyebabkan kerugian untuk diri sendiri dan orang lain (Parker, et.al, 1995).

Keselarasan atau kesesuaian perilaku individu dalam suatu kelompok dengan nilai dan harapan kelompoknya biasanya sejalan. Hal ini sesuai dengan kecenderungan manusia untuk hidup berkelompok yang pada akhirnya membentuk norma sosial (Sherif; Taylor, Peplau \& O'sear, 2009). Kecenderungan untuk hidup berkelompok tersebut merupakan alasan utama individu larut dan melebur dengan kelompoknya untuk mendapatkan persetujuan atau menghindari ejekan dari kelompok yang diikutinya (Baron \& Byrne, 2007).

Berdasarkan penelitian terdahulu, norma-norma moral yang berpihak pada perilaku ngebut akan mempunyai prediksi yang signifikan pada intensi untuk ngebut. Sebagian besar studi yang menunjukkan norma-norma moral pada intensi tidak menunjukkan dampak serupa pada perilaku, setidaknya saat faktor Intensi dimasukkan ke dalam analisis penelitian (Godin, Conner \& Sheeran, 2005). Hakim \& Nuqul (2011) menganalisa sikap aturan lalu-lintas pada komunitas bermotor di Kota Malang dan menemukan bahwa norma kelompok mempengaruhi perilaku aggotanya dalam berlalu-lintas.

\section{Pengendalian Terukur (Perceived Control) Theory of Reasoned Action (TRA)}

Sebagian besar teori perilaku yang sehat meyakini bahwa satu-satunya alat prediksi terbaik perilaku individu hanyalah niatnya untuk terlibat dalam perilaku itu (Traffic, Sonja, \& Road, 2018). Theory of Reason Action dinilai tepat dalam menjelaskan pengaruh sikap dan norma subjektif dalam perilaku berkendara (Fishben \& Ajzen, 1980). Penelitian lain menyatakan bahwa respon emosional berpengaruh dan mendorong dilakukannya perilaku berisiko seperti perilaku ngebut, walaupun ada hal lain yang lebih mendasari perilaku 
tersebut misalkan terlambat untuk menepati sebuah janji, atau menjaga agar lalu lintas tetap lancar atau niat yang tidak disengaja (Jones, Ferguson, \& Robinson, 2012).

Menurut Theory of Reasoned Action (TRA), intensi (niat) adalah prediktor yang proksimal dan menghubungkan sikap (attitude) dan norma subjektif dan variabel lain (seperti kepribadian) pada perilaku (Sheeran, 2017). Definisi dari intensi adalah sejumlah usaha yang mau dikerahkan seseorang untuk mencapai tujuan. Tindakan dikendalikan oleh intensi, tetapi tidak semua intensi dilakukan atau diwujudkan, beberapa diabaikan sementara sebagian direvisi agar sesuai dengan keadaan yang terus berubah (From Intentions to Actions: A Theory of Planned Behavior, 1985).

Theory of Reasoned Action (TRA) menerangkan perilaku yang berubah berdasarkan hasil dari intensi perilaku, dimana intensi perilaku untuk melakukan atau untuk tidak melakukan perilaku tertentu dipengaruhi oleh dua hal. Yang pertama adalah attitude towards behavior atau sikap individu terhadap perilaku berdasarkan kepercayaan individu tersebut. Yang kedua adalah subjective norms atau norma subyektif yang mendeskripsikan kepercayaan individu mengenai perilaku yang normal dan dapat diterima dalam masyarakat (Behavior \& Ajzen, 2019).

\section{Theory of Planned Behavior}

Theory of Planned Behavior (TBP) memperbarui asumsi dasar dari TRA bahwa niat adalah prediktor perilaku paling penting tetapi mengakui bahwa individu mungkin tidak selalu memiliki kendali yang cukup untuk mengambil tindakan atas niat yang individu itu miliki (From Intentions to Actions: A Theory of Planned Behavior, 1985). Kendali atas perilaku tersebut mampu membuat intensi atau niat tersebut tidak dilaksanakan.

Theory of Planned Behavior (TBP) melengkapi TRA dengan menambahkan kepercayaan individu dan persepsi individu bahwa individu tersebut memilliki kemampuan untuk melakukan kontrol atas perilakunya. Teori ini menggarisbawahi bahwa Intensi untuk melakukan perilaku tertentu dapat diprediksi dengan akurasi tinggi dari sikap terhadap perilaku, norma subyektif, dan kontrol perilaku yang dirasakan oleh individu yang bersangkutan.

Beberapa penelitian terkini tentang perilaku memiliki asumsi bahwa "orang melakukan apa yang ingin mereka lakukan" dan "tidak melakukan apa yang tidak ingin mereka lakukan". Intensi seringkali diukur dengan respon seseorang terhadap pernyataan seperti "saya bermaksud melakukan x" atau "saya bermaksud tidak akan melakukan x".

Tipe intensi dapat dibedakan menjadi intensi positif dan intensi negatif. Intensi positif atau tendensi dapat merujuk pada niat melakukan suatu perilaku dan untuk tidak melakukan suatu perilaku. Hal yang menjadi perhatian selanjutnya adalah apakah orang tersebut berniat untuk bertindak (Sheeran, 2017). Selanjutnya, proses yang menjelaskan bagaimana konsistensi niat mempengaruhi perilaku dapat ditunjukkan pada tabel berikut ini:

Tabel 2. Konsistensi antara Intensi dan Perilaku

\begin{tabular}{ccc}
\hline Perilaku yang mengikutinya & \multicolumn{2}{c}{ Intensi } \\
\cline { 2 - 3 } & Positif & Negatif \\
\hline Bertindak & Pelaku yang cenderung & Pelaku yang segan \\
\hline Tidak bertindak & $\begin{array}{c}\text { Pemantang (abstainer) } \\
\text { cenderung }\end{array}$ & Pemantang yang segan \\
\hline
\end{tabular}

Sumber: Sheeran, 2017

Tabel 2 tersebut menjelaskan konsistensi antara niat dan perilaku, dimana terdapat dua kelompok. Kelompok dengan niat yang positif yang kemudian akan bertindak (ditetapkan sebagai orang yang cenderung) dan kelompok dengan intensi negatif yang tidak mengambil tindakan apa-apa (orang tidak melakukan tindakan) (Sheeran, 2017). Keputusan untuk bertindak atau tidak bertindak adalah hasil pertimbangan dari kemungkinan hasil spesifik yang melekat pada tindakan individu tersebut.

Ruang lingkup Intensi dipengaruhi oleh kebiasaan dan otomatisitas dalam perilaku manusia (Sheeran, 2017). Penelitian sebelumnya tentang speeding behavior dilakukan untuk mengetahui perilaku ngebut (Jones et al., 2012) berdasarkan indikator TBP dasar dengan memasukkan unsur emosi. Penelitian tersebut tidak dikhususkan untuk daerah sekolah melainkan jalan umum. Penelitian lain yang dilakukan oleh (Richards, 2010) menemukan adanya hubungan antara kecepatan dengan risiko kecelakaan fatal. 
Dari beberapa penelitian terdahulu, dalam konteks keselamatan jalan umumnya dan Zona Selamat Sekolah, maka studi ini mencoba mengkaji apa yang mempengaruhi intensi pelanggaran batas kecepatan maksimal pada Zona Selamat Sekolah di Daerah Khusus Ibukota Jakarta pada tahun 2020, dengan menggunakan model teori perilaku terencana (Theory of Planned Behavior). Untuk mengetahui keterkaitan pengaruh antara variabel dapat dijelaskan pada kerangka pemikiran berikut ini :

1) Hubungan antara Sikap dengan Intensi pelanggaran batas kecepatan maksimal di Zona Selamat Sekolah. Intensi (niat) untuk ngebut didasarkan pada sikap (attitude) individu dimana sikap dipengaruhi oleh kebiasaan dan otomatisitas dalam perilaku manusia. Sikap dapat memiliki hubungan dengan intensi pelanggaran batas kecepatan maksimal di Zona Selamat Sekolah.

2) Hubungan antara Norma Subjektif dengan Intensi pelanggaran batas kecepatan maksimal di Zona Selamat Sekolah.

Norma Subjektif mencerminkan kepercayaan normatif yang dimiliki individu, yang mewakili persepsi mengenai penilaian masyarakat yang sigifikan mengenai apakah perilaku tersebut harus dilakukan atau tidak. Norma Subjektif dapat memiliki hubungan dengan intensi pelanggaran batas kecepatan maksimal di Zona Selamat Sekolah

3) Hubungan antara Pengendalian Terukur dengan Intensi pelanggaran batas kecepatan maksimal di Zona Selamat Sekolah.

Perilaku memiliki asumsi bahwa "orang melakukan apa yang ingin mereka lakukan" dan "tidak melakukan apa yang tidak ingin mereka lakukan". Intensi seringkali diukur dengan respon seseorang terhadap pernyataan seperti "saya bermaksud melakukan $\mathrm{x}$ " atau "saya bermaksud tidak akan melakukan x". Pengendalian terukur mencerminakan kepercayaan individu dan persepsi individu bahwa individu tersebut memilliki kemampuan untuk melakukan kontrol atas perilakunya. Pengendalian Terukur dapat memiliki hubungan dengan intensi pelanggaran batas kecepatan maksimal di Zona Selamat Sekolah.

4) Hubungan antara Jenis Kelamin dengan Intensi pelanggaran batas kecepatan maksimal di Zona Selamat Sekolah.

Jenis kelamin atau gender mempengaruhi cara individu dalam mempercayai sesuatu, meyakini sesuatu, merespon sesuatu, dan melakukan pengendalian atas tindakannya. Jenis Kelamin dapat memiliki hubungan dengan intensi pelanggaran batas kecepatan maksimal di Zona Selamat Sekolah.

5) Hubungan antara Usia Muda dengan Intensi pelanggaran batas kecepatan maksimal di Zona Selamat Sekolah.

Usia Muda mempengaruhi mempengaruhi cara individu dalam mempercayai sesuatu, meyakini sesuatu, merespon sesuatu, dan melakukan pengendalian atas tindakannya. Usia Muda dapat memiliki hubungan dengan intensi pelanggaran batas kecepatan maksimal di Zona Selamat Sekolah.

6) Hubungan antara Pendidikan dengan Intensi pelanggaran batas kecepatan maksimal di Zona Selamat Sekolah.

Pendidikan mempengaruhi cara individu dalam mempercayai sesuatu, meyakini sesuatu, merespon sesuatu, dan melakukan pengendalian atas tindakannya. Pendidikan dapat memiliki hubungan dengan intensi pelanggaran batas kecepatan maksimal di Zona Selamat Sekolah.

7) Hubungan antara kepemilikan SIM dengan Intensi pelanggaran batas kecepatan maksimal di Zona Selamat Sekolah.

Kepemilikan SIM mempengaruhi cara individu dalam mempercayai sesuatu, meyakini sesuatu, merespon sesuatu, dan melakukan pengendalian atas tindakannya. Kepemilikan Surat Ijin Mengemudi dapat memiliki hubungan dengan intensi pelanggaran batas kecepatan maksimal di Zona Selamat Sekolah.

\section{METODE}

Penelitian ini menggunakan metode kuantitatif, dimana data yang diperoleh akan disajikan dalam bentuk angka (numerik) dan akan dianalisis lebih lanjut dalam suatu analisis data. Data yang dianalisis adalah data yang terdiri atas delapan variabel penelitian, yaitu Intensi Pelanggaran Batas Kecepatan Maksimal sebagai variabel terikat (dependent variable), Sikap, Norma Subjektif, Pengendalian Terukur, Gender, Usia, Pendidikan, dan kepemilikan SIM sebagai variabel bebas (independent variables). 
Penelitian ini menggunakan data primer yang dilakukan dengan survei online di bulan Juni dan Juli 2020. Survei didistribusikan melalui media sosial di berbagai kelompok pendidikan dan pusat komunitas di Jakarta yang meliputi 5 wilayah berbeda yaitu Jakarta Pusat, Jakarta Utara, Jakarta Timur, Jakarta Selatan dan Jakarta Barat.

Populasi dalam penelitian ini adalah seluruh penduduk Daerah Khusus Ibukota Jakarta dan juga penduduk Bodetabek (Bogor, Depok, Tangerang dan Bekasi) yang beraktivitas (bekerja, belajar dan melakukan perjalanan) di DKI Jakarta. Sampel adalah bagian dari jumlah atau karakteristik tertentu yang diambil dari suatu populasi yang akan diteliti secara rinci (Sugiyono, 2009). Sampel yang akan diambil dalam penelitian ini dilakukan dengan metode online survey sesuai dengan tata cara yang berlaku sehingga dapat merepresentatifkan populasi yang diwakilinya.

\section{HASIL DAN PEMBAHASAN}

\section{Uji Validitas Data}

Untuk menguji validitas dari suatu data penelitian dapat menggunakan analisis pearson correlation dimana jika total dari analisis menunjukkan nilai $r$ hitung > nilai $r$ tabel maka data penelitian dinyatakan valid. Hasil Pengujian validitas data dapat dilihat pada tabel 3. dibawah ini :

Tabel 3. Uji Validitas Data

\begin{tabular}{cccc}
\hline Pernyataan & r hitung & $\begin{array}{c}\text { r tabel } \\
\text { (product moment untuk N=252) }\end{array}$ & $\begin{array}{c}\text { Valid } \\
\text { r hitung }>\text { r tabel }\end{array}$ \\
\hline & \multicolumn{2}{c}{ Sikap } & valid \\
\hline 1 & 0,500759404 & 0,126 & valid \\
\hline 2 & 0,534880743 & 0,126 & valid \\
\hline 3 & 0,517217467 & 0,126 & valid \\
\hline 4 & 0,592269731 & 0,126 & valid \\
\hline & & Norma Subjektif & valid \\
\hline 1 & 0,622754053 & 0,126 & valid \\
\hline 2 & 0,713008641 & 0,126 & valid \\
\hline 3 & 0,756846977 & 0,126 & valid \\
\hline 4 & 0,591783965 & 0,126 & valid \\
\hline & & 0,126 & valid \\
\hline 1 & 0,605138494 & 0,126 & valid \\
\hline 2 & 0,558659248 & 0,126 & valid \\
\hline 3 & 0,62275921 & 0,126 & valid \\
\hline 4 & 0,619958062 & 0,126 & valid \\
\hline & & 0,126 &
\end{tabular}

Sumber: Data primer, diolah Peneliti, 2020

Dari Tabel 3. terlihat bahwa dalam pengujian validitas, koefisien korelasi Pearson Product Moment ( $\rho$ atau r) digunakan sebagai batas valid atau tidaknya sebuah butir pernyataan. Dengan jumlah N 252 dan taraf nyata 5\%, maka menggunakan uji $\mathrm{r}$ pearson correlation semua variabel dinyatakan valid, hal ini terlihat dari nilai r-hitung untuk semua variabel di atas lebih besar dari nilai r-tabel yaitu dengan tingkat signifikansi 5\% menggunakan uji dua sisi (two tail test).

\section{Uji Reliabilitas Data}

Tingkat reliabel suatu variabel atau konstruk penelitian dapat dilihat dari hasil uji statistik Cronbach

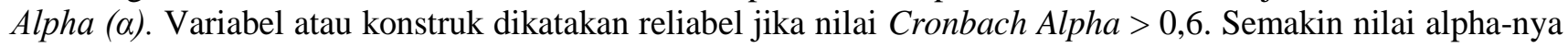


mendekati satu maka nilai reliabilitas datanya semakin terpercaya. Hasil pengujian reliabilitas dapat dilihat pada tabel 4 dibawah ini :

Tabel 4 Uji Reliabilitas

\begin{tabular}{cccc}
\hline Variabel & Cronbach's Alpha & Ketetapan & Keterangan \\
\hline Sikap & 0,6694 & 0,6 & Reliabel \\
\hline Norma Subjektif & 0,9171 & 0,6 & Reliable \\
\hline Pengendalian Terukur & 0,90314 & 0,6 & Reliable \\
\hline Intensi & 0.9844 & 0,6 & Reliable \\
\hline
\end{tabular}

Sumber: Data primer, diolah Peneliti, 2020

Dari tabel 4 terlihat bahwa semua variabel reliabel (konsisten), hal ini terlihat dari nilai cronbach alpha dari semua variabel memiliki nilai diatas 0,6 .

Dalam analisis regresi linear berganda, melakukan uji asumsi klasik adalah wajib untuk mendapatkan nilai parameter yang efisien dan tidak bias atau BLUE (Best Linear Unviased Estimator) dari persamaan regresi linear berganda dengan metode kuadrat terkecil, maka perlu dilakukan pengujian untuk mendeteksi bahwa model reresi yang dihasilkan memenuhi persyaratan atau asumsi klasik.

\section{Pengujian Hipotesis}

\section{Analisis Regresi Linear Berganda}

Analisis regresi linear berganda digunakan untuk mengetahui besarnya pengaruh Sikap (SIKAP), Norma Subjektif (NORMA), Pengendalian Terukir (KONTROL), Jenis Kelamin (GENDER), Usia (USIA), Pendidikan (EDUC) dan Kepemilikan SIM (SIM) secara simultan terhadap Intensi Pelanggaran Batas Kecepatan Maksimal (INTENSI). Pengujian hipotesis dalam penelitian ini menggunakan analisis regresi berganda (multiple regression analysis). Hasil pengujian untuk hipotesis 1 sampai dengan 7 dapat terlihat pada tabel 5 dibawah ini :

Tabel 5 Analisis Regresi Linear Berganda

\begin{tabular}{ccccc}
\hline Variable & Coefficient & Std. Error & t-Statistic & Prob. \\
\hline C & 5.934503 & 1.180046 & 5.029045 & 0.0000 \\
\hline SIKAP & 0.046677 & 0.070380 & 0.663218 & 0.5078 \\
\hline NORMA & 0.117794 & 0.056021 & 2.102675 & 0.0365 \\
\hline KONTROL & 0.087616 & 0.060095 & 1.457962 & 0.1461 \\
\hline GENDER & -0.051937 & 0.280432 & -0.185204 & 0.8532 \\
\hline USIA & 0.278844 & 0.353670 & 0.788432 & 0.4312 \\
\hline EDUC & 0.171001 & 0.266303 & 0.642131 & 0.5214 \\
\hline SIM & 0.075307 & 0.277086 & 0.271782 & 0.7860 \\
\hline R-squared & 0.089825 & Mean dependent var & 10.37302 \\
\hline Adjusted R-squared & 0.063713 & S.D. dependent var & 1.944383 \\
\hline S.E. of regression & 1.881422 & Akaike info criterion & 4.133164 \\
\hline Sum squared resid & 863.6986 & Schwarz criterion & 4.245209 \\
\hline Log likelihood & -512.7786 & Hannan-Quinn criter. & 4.178249 \\
\hline F-statistic & 3.440032 & Durbin-Watson stat & 1.898962 \\
\hline Prob(F-statistic) & 0.001575 & & \\
\hline Dependent Varable & INTESI & \\
\hline
\end{tabular}

Dependent Variable: INTENSI

Method: Least Squares

Date: 08/09/20 Time: 16:11

Sample: 1252 
Included observations: 252

Sumber: Eviews10, diolah Peneliti, 2020

Hasil regresi menunjukkan bahwa berdasarkan tabel diatas, untuk sampel yang diteliti maka dapat diperoleh rumus regresi sebagai berikut:

\title{
Intensi $=5.934503+0.117794$ Norma $+e$
}

Interpretasi dari regresi tersebut adalah sebagai berikut:

a) Konstanta (a)

Nilai konstanta $\mathrm{a}=5,934503$ memberikan arti bahwa jika variabel bebas diabaikan atau dengan kata lain jika tidak ada variabel SIKAP, NORMA, KONTROL, GENDER, USIA, EDUC dan SIM, maka INTENSI akan bernilai 5,934503.

b) Norma (Norma Subjektif)

Nilai koefisien b2 untuk variabel Norma sebesar 0.117794 dan bertanda positif. Hal ini menunjukkan Norma Subjektif mempunyai hubungan searah dengan Intensi, mengartikan bahwa setiap perubahan satu satuan pada Norma Subjektif dengan asumsi variabel SIKAP, KONTROL, GENDER, USIA, EDUC dan SIM konstan, maka INTENSI akan mengalami peningkatan sebesar $11.77 \%$ dan bergerak ke arah yang sama.

\begin{abstract}
Analisis Koefisien Determinasi $\left(\mathbf{R}^{2}\right)$
Koefisien determinasi digunakan untuk mengetahui seberapa besar hubungan dari beberapa variabel dalam pengertian yang lebih jelas. Koefisien determinasi akan menjelaskan seberapa besar perubahan atau variasi suatu variabel bisa dijelaskan oleh perubahan atau variasi pada variabel yang lain (Santosa \& Ashari, 2005:125). Dalam bahasa sehari-hari adalah kemampuan variabel bebas di luar model untuk berkontribusi terhadap variabel tetapnya dalam persentase. Nilai koefisien ini antara 0 dan 1 , jika hasil lebih mendekati angka 0 berarti kemampuan variabel-variabel independen dalam menjelaskan variasi variabel amat terbatas. Tapi jika hasil mendekati angka 1 berarti variabel-variabel independen memberikan hampir semua informasi yang dibutuhkan untuk memprediksi variasi variabel dependen. Untuk analisisnya dengan menggunakan output EViews dapat dilihat pada tabel 3.9.

Berdasarkan Tabel 3.9. di atas nilai $\mathbf{R}^{2}=0,089825$, yang berarti bahwa variabel Norma Subjektif (Norma) dapat menjelaskan variabel Intensi sebesar 8,98 \%, sedangkan 91,02 \% dijelaskan oleh variabel lain dil luar model variabel lain yang tidak diteliti. Karena nilai $R$ Square cenderung jauh dari nilai 1 maka dapat disimpulkan bahwa variabel-variabel independen tidak memberikan semua informasi yang dibutuhkan untuk memprediksi variasi dependen.
\end{abstract}

\section{UJI T}

Uji t ditunjukkan dengan nilai "t-statistics" digunakan untuk mengetahui apakah variabel-variabel independen secara parsial berpengaruh nyata atau tidak terhadap variabel dependen. Derajat signifikansi yang digunakan adalah 0,05. Apabila nilai signifikan lebih kecil dari derajat kepercayaan maka kita menerima hipotesis alternatif, yang menyatakan bahwa suatu variabel independen secara parsial mempengaruhi variabel dependen. Analisis uji t juga dilihat dari tabel" Coefficient". Dari tabel hasil regresi di atas maka diperoleh:

- Norma terhadap Intensi

Terlihat pada tabel 4.10 kolom $t$ statistics terdapat nilai sig 2.102675. Nilai sig lebih besar dari nilai probabilitas 0,05 , atau nilai p $0,0365<0,05$, maka $\mathrm{H}_{0}$ ditolak dan $\mathrm{H}_{\mathrm{a}}$ diterima,. Variabel Norma mempunyai $t_{\text {hitung }}$ yakni 2,102675 dengan $t_{\text {tabel }(0,05)}=2,0422$. Dengan menggunakan uji 2 sisi maka $t_{\text {hitung }}>t_{\text {tabel }}$ untuk level of significance 95\% ( 2,102675 > 2,0422), dapat disimpulkan bahwa variabel Norma Subjektif berpengaruh terhadap Intensi, namun dengan toleransi tingkat kesalahan $(\propto)=5 \%$.

\section{Uji F Statistik}

Uji F digunakan untuk mengetahui apakah variabel-variabel independen secara simultan berpengaruh signifikan terhadap variabel dependen. Derajat kepercayaan yang digunakan adalah 0,05. Apabila nilai F hasil perhitungan lebih besar daripada nilai $\mathrm{F}$ menurut tabel maka hipotesis alternatif, yang menyatakan bahwa semua variabel independen secara simultan berpengaruh signifikan terhadap variabel dependen. 
Pengujian ini dilakukan untuk melihat apakah secara bersama-sama atau simultan variabel SIKAP, NORMA, KONTROL, GENDER, USIA, EDUC dan SIM secara simultan berpengaruh signifikan terhadap INTENSI. Untuk analisisnya dari output Eviews10 dapat dilihat dari Tabel 4.10 hasil regresi. Dari tabel 4.10 diperoleh nilai $F_{\text {hitung }}$ sebesar 3,440032 dengan nilai probabilitas (sig) $=0,001575$. Nilai $F_{\text {hitung }}(3.440032)>$ $\mathrm{F}_{\text {tabel }}(2,06)$, dan nilai sig. lebih kecil dari nilai probabilitas 0,05 atau nilai $0,000<0,05$; maka $\mathrm{H}_{1}$ diterima, berarti secara bersama-sama (simultan) variabel SIKAP, NORMA, KONTROL, GENDER, USIA, EDUC dan SIM secara serentak berpengaruh signifikan terhadap INTENSI.

\section{KESIMPLAN DAN SARAN}

Penelitian ini menganalisis tentang Intensi Pelanggaran Batas Kecepatan Maksimal di Zona Selamat Sekolah di lima wilayah yang berbeda yaitu Jakarta Pusat, Jakarta Timur, Jakarta Selatan, Jakarta Barat dan Jakarta Utara. Dengan menggunakan survei atas 252 responden dan serangkain uji analisis dan statistik diperoleh kesimpulan, implikasi hasil penelitian dan saran-saran untuk bahan pertimbangan dalam pengambilan keputusan dalam kebijakan lalu-lintas.

\section{Kesimpulan}

Dari data yang didapatkan dan dianalisis yang telah dilakukan, maka penelitian ini membuktikan:

1) Berdasarkan uji t (t-test) untuk variabel Sikap tidak berpengaruh signifikan terhadap Intensi Pelanggaran Batas Kecepatan Maksimal di ZoSS, hal ini memberikan penjelasan bahwa Sikap yang dimiliki responden tidak cukup menjelaskan apakah Intensi Pelanggaran Batas Kecepatan dapat diindikasikan dari sikap yang dimiliki oleh sampel penelitian ini.

2) Berdasarkan uji $\mathrm{t}$ (t-test) untuk variabel Norma Subjektif (Norma) berpengaruh signifikan terhadap Intensi Pelanggaran Batas Kecepatan Maksimal di ZoSS, hal ini memberikan penjelasan bahwa Norma-Norma Subjektif dan Norma-Norma Moral yang dimiliki responden dalam sampel penelitian ini sangat menjelaskan pengaruhnya terhadap Intensi Pelanggaran Batas Kecepatan. Hal ini menjelaskan bahwa pengaruh lingkungan terhadap Intensi cukup signifikan. Dengan adanya nilai-nilai di lingkungan masyarakat dan edukasi serta sosialisasi bahwa niat ngebut adalah hal yang membahayakan dan dapat merugikan diri sendiri dan orang lain, dan juga adanya sanksi sosial dan hukum jika melakukan perilaku itu, maka Intensi Pelanggaran Batas Kecepatan Maksimal di ZoSS dapat diminimalkan.

3) Berdasarkan uji t (t-test) untuk variabel Pengendalian Terukur tidak berpengaruh signifikan terhadap Intensi Pelanggaran Batas Kecepatan Maksimal di ZoSS, hal ini memberikan penjelasan bahwa Pengendalian Terukur yang dimiliki responden tidak cukup menjelaskan apakah Intensi Pelanggaran Batas Kecepatan dapat diindikasikan dari Pengendalian Terukur yang dimiliki oleh sampel penelitian ini.

4) Berdasarkan uji t (t-test) untuk variabel Jenis Kelamin tidak berpengaruh signifikan terhadap Intensi Pelanggaran Batas Kecepatan Maksimal di ZoSS, hal ini memberikan penjelasan bahwa Jenis Kelamin yang dimiliki responden tidak cukup menjelaskan apakah Intensi Pelanggaran Batas Kecepatan dapat diindikasikan dari Jenis Kelamin responden dalam sampel penelitian ini.

5) Berdasarkan uji t (t-test) untuk variabel Usia tidak berpengaruh signifikan terhadap Intensi Pelanggaran Batas Kecepatan Maksimal di ZoSS, hal ini memberikan penjelasan bahwa Usia yang dimiliki responden tidak cukup menjelaskan apakah Intensi Pelanggaran Batas Kecepatan dapat diindikasikan dari Usia responden dalam sampel penelitian ini.

6) Berdasarkan uji t (t-test) untuk variabel Pendidikan tidak berpengaruh signifikan terhadap Intensi Pelanggaran Batas Kecepatan Maksimal di ZoSS, hal ini memberikan penjelasan bahwa Pendidikan yang dimiliki responden tidak cukup menjelaskan apakah Intensi Pelanggaran Batas Kecepatan dapat diindikasikan dari Pendidikan responden dalam sampel penelitian ini. Berdasarkan uji t (t-test) untuk variabel Kepemilikan Surat Ijin Mengemudi tidak berpengaruh signifikan terhadap Intensi Pelanggaran Batas Kecepatan Maksimal di ZoSS, hal ini memberikan 
penjelasan bahwa Kepemilikan Surat Ijin Mengemudi yang dimiliki responden tidak cukup menjelaskan apakah Intensi Pelanggaran Batas Kecepatan dapat diindikasikan dari Kepemilikan Surat Ijin Mengemudi responden dalam sampel penelitian ini.

\section{Implikasi Hasil Penelitian}

1) Hasil penelitian ini menunjukkan bahwa masih dibutuhkan penelitian-penelitian lanjutan untuk mengkaji banyak aspek dari perilaku berlalu-lintas.

2) Aspek-aspek dalam penelitian tersebut sangat dibutuhkan untuk merumuskan kebijakan publik berupa aturan dan perlakuan yang tepat berlalu-lintas.

3) Hasil penelitian ini dapat menjadi masukan bagi pihak perguruan tinggi untuk melakukan penelitian lebih jauh, juga sebagai masukan untuk pengambil kebijakan dan industri terkait lainnya untuk mengembangkan program keselamatan yang tepat guna mengantisipasi dan memitigasi intensi pelanggaran batas kecepatan maksimal di Zona Selamat Sekolah

\section{Saran}

Berdasarkan hasil dari penelitian di atas, peneliti menggaris bawahi beberapa poin sebagai pertimbangan Pemerintah Kota Provinsi DKI Jakarta atas Intensi Pelanggaran Batas Kecepatan Maksimal di Zona Selamat Sekolah. Adapun poin-poin tersebut adalah sebagai berikut:

1) Sosialisasi tentang Zona Selamat Sekolah harus lebih ditingkatkan sehingga semua kalangan masyarakat, baik yang berdomisili di daerah sekolah tersebut atau masayarakat luas yang sedang melintas paham tentang Zona Selamat Sekolah.

2) Dibutuhkan sosialisasi di setiap sekolah yang memiliki ruas jalan tertentu yang termasuk dalam kategori ZoSS, untuk meningkatkan keselamatan para pengguna jalan.

3) Perlu dibangun kesadaran masyarakat umum dan komunitas-komunitas tentang pentingnya budaya keselamatan jalan untuk pengguna jalan.

4) Marka dan rambu-rambu lalu lintas yang terkait dengan Zona Selamat Sekolah dapat dirawat secara berkala, untuk menghindari pelanggaran lalu lintas di daerah ZoSS yang disebabkan oleh ketidaktersediaan atau tidak terinformasinya marka dan rambu jalan. 


\section{Daftar Pustaka}

Ajzen, I. (1985). From Intentions to Actions : A Theory of Planned Behavior.

Ajzen, I. (1991). The Theory of Planned Behavior. In ORGANIZATIONAL BEHAVIOR AND HUMAN DECISION $\begin{array}{llllll}\text { PROCESSES (Vol. } & \text { 211, } & \text { 179-211). } & \text { Retrieved from }\end{array}$ https://www.dphu.org/uploads/attachements/books/books_4931_0.pdf

Ajzen, I. (2005). Attitudes, Personality and Behaviour (Second). Retrieved from https://psicoexperimental.files.wordpress.com/2011/03/ajzeni-2005-attitudes-personality-and-behaviour-2nd-edopen-university-press.pdf

Altmann, T. K. (2017). Attitude : A Concept Analysis. Journal Compilation @ (2008), Wiley Periodicals, Inc., (October). https://doi.org/10.1111/j.1744-6198.2008.00106.x

BANAJI, MAHZARIN R. , HEIPHETZ, L. (1985). Chapter 10 Attitudes. Retrieved from https://sites.fas.harvard.edu/ mrbworks/articles/2010_attitudes.pdf

Behavior, O., \& Ajzen, I. (2019). The Theory of Planned Behavior The Theory of Planned Behavior. 5978(December 1991). https://doi.org/10.1016/0749-5978(91)90020-T

Cancercontrol.cancer.gov/brp/research/construct. (1991). Behavioral Intentions, Expectations and Willingness. 1-17.

Gujarati, Damodar N. \& Porter, D. C. (2009). Basic Econometrics (Fifth). The McGraw-Hill Series Economics.

Hakim, Lukman; Nuqul, F. L. (2011). Analisa-Sikap-Terhadap-Aturan-Lalu-Lintas-Pada-Komunitas-Bermotor.pdf (p. 11). p. 11.

Handayani, S., Mulyani, T., \& Iqbal, M. (2019). Budaya Keselamatan pada Transportasi Jalan Indonesia Safety Culture $i$ n Indonesia 's Road Transport. 201-210.

Indonesian Central Agency of Statistics. (2019). Bps-File (3).

Jones, C., Ferguson, C., \& Robinson, K. (2012). Emotion and Speeding Intention : Predicting intention and differences between intenders and non-intenders. (October), 1-10.

Kamal, I., Wulandari, S., \& Gunawan, A. (2019). PENERAPAN ZONA SELAMAT SEKOLAH ( ZoSS ) TERHADAP. 5(3), $353-358$.

Kemdikbud. (n.d.). Data Sekolah Provinsi DKI Jakarta. Retrieved from https://dapo.dikdasmen.kemdikbud.go.id/sp/1/010000

Kementerian-Perhubungan. (2018). PERDIRJEN_SK_3582.pdf. Retrieved from http://hubdat.dephub.go.id/keputusandirjen/tahun-2018/2768-sk-3582aj

Majid, U. (2018). Research Fundamentals : Study Design, Population, and Sample Size. Majid et Al. | URNCST Journal (2018): Volume 2, Issue 1, (January). https://doi.org/10.26685/urncst.16

Nurlaila. (2003). Bab II Tinjauan Pustaka. Retrieved from http://digilib.unimus.ac.id/files/disk1/104/jtptunimus-gdlnurlailag2-5198-3-bab2.pdf

Red Cross. (2007). Practical Guide on Road Safety: A Toolkit for National Red Cross and Red Crescent Societies.

Richards, D. C. (2010). Road Safety Web Publication No . 16 Relationship between Speed and Risk of Fatal Injury: Pedestrians and Car Occupants. (16).

Sheeran, P. (2017). Intention - Behavior Relations : A Conceptual and Empirical Review European Review of Social Psychology. (January 2002). https://doi.org/10.1080/14792772143000003

Traffic, P. F., Sonja, F., \& Road, S. N. (2018). Intention to speed in a rural area: Reasoned but not reasonable. (July 2010). https://doi.org/10.1016/j.trf.2010.04.002

World Health Organization. (2014). Road safety : basic facts. 23. 